\title{
Floristic analysis of domestic gardens in the Tlokwe City Municipality, South Africa
}

\author{
C.S. LUBBE*, S.J. SIEBERT* and S.S. CILLIERS*
}

Keywords: Agavaceae, alien plants, Asteraceae, diversity, grassland, home gardens, native plants, Potchefstroom, urban ecology

\section{ABSTRACT}

This paper is a first attempt to describe the flora of domestic gardens from an urban environment in South Africa. A total of 835 plant species of 501 genera in 145 families was recorded from 100 gardens in a $54.9 \mathrm{~km}^{2}$ area of the Tlokwe City Municipality [Potchefstroom], North-West Province. A substantial number of alien species (580) were recorded, but also many indigenous species (255) that included South African endemics (61) and protected species on the National Red Data List (18). A number of the alien species that were commonly cultivated are declared invasive plants in South Africa (88). Most of the cultivated indigenous taxa originated from the southeastern provinces of South Africa.

This study provides new knowledge on the often overlooked biodiversity of urban areas in a developing, mega-diverse country. Most studies of a similar nature were conducted in the developed countries of Europe and are of limited use in the development of management plans of urban ecosystems in southern Africa.

\section{INTRODUCTION}

Urbanization is one of the most significant demographic trends of all times (Pickett et al. 2001) and it has a devastating impact on the environment (Wu et al. 2003). The increase in population density of urban areas (Pickett et al. 2001) results in infrastructure development and the subsequent transformation of natural areas. Significant changes in biological and spatial composition alter the structure of ecosystems, which in turn influence the processes underlying such ecosystems, for example nutrient cycles, water relations and climate systems $(\mathrm{Wu}$ et al. 2003). Plants play an important role in sustaining urban ecosystems (Savard et al. 2000; Colding 2007). Urban green spaces provide physical ecosystem services such as temperature and flood control, removal of carbon from the atmosphere and social ecosystem services such as the increase of aesthetic values and community wellbeing (Bolund \& Hunhammar 1999; Alberti 2005; Hope et al. 2006). Knowledge of urban vascular plant floras is therefore a prerequisite to maintaining and improving these ecosystem services of the urban environment and to keep it favourable for life within to persist.

Globally, urban vascular plant floras have higher diversity than that of the surrounding countryside. This trend was noted in California and Phoenix, Arizona in the USA (Hope et al. 2003; Williams et al. 2005), Brussels in Belgium (Godefroid \& Koedam 2007) and several cities in Germany (Kühn et al. 2004). In Sheffield, England, the gamma diversity recorded in a relatively small number of domestic gardens equalled that of the native flora in the area, and was expected to become much higher with increasing sample size (Smith et al. 2006). The comparatively higher gamma diversity of urban vegetation is mainly the result of the high spatiotemporal heterogeneity in urban environments (Rebele 1994) and an increasing dispersal of alien plant spe-

\footnotetext{
* School of Environmental Sciences and Development, North-West University, Private Bag X6001, Potchefstroom 2520, South Africa. Email: stefan.siebert@ nwu.ac.za. MS. received: 2010-09-15.
}

cies via global transportation and other human actions (McKinney 2008).

The richness of garden floras is related to the size of the species pool available to gardeners (Thompson et al. 2003). A list containing more than 70000 plant species that are available from United Kingdom nurseries was compiled by Macaulay et al. (2009), while Isaacson (2004) presented a list that consisted of 90000 plant species available for sale in the USA. Glen (2002) published a book on the cultivated plants of southern Africa that contains \pm 37000 species (not claimed to be a fully comprehensive list), compared with the little over 21800 species in the native flora of southern Africa (Germishuizen et al. 2006).

The aim of this study is to present a first total floristic survey of domestic gardens in a typical, medium-sized, southern African city. Objectives were to analyse and describe the plant diversity found in domestic gardens at family, genus and species levels, to determine the origin of species under cultivation, and assess the endemic, threatened, useful and invasive plant species in the garden flora. The analysis provides baseline information with which to compare garden floras of other cities and countries, and will contribute to the establishment of a broader understanding of the management and conservation potential of this land use type. Additionally, the comparison of the garden flora with the flora of other urban open spaces (other land use types) in the Tlokwe City Municipality (Cilliers 1998) will shed light on the contribution that domestic gardens make towards total urban plant diversity.

\section{STUDY AREA}

This study was conducted in the Tlokwe City Municipality (TCM) in the North-West Province, which is situated between $26^{\circ} 39^{\prime}$ and $26^{\circ} 44^{\prime}$ latitude and $27^{\circ} 00^{\prime}$ and $27^{\circ} 08^{\prime}$ longitude (Figure 1). It includes the town of Potchefstroom, the township areas of Ikageng, Promosa and Mohadin, the surrounding smallholdings, and infor- 


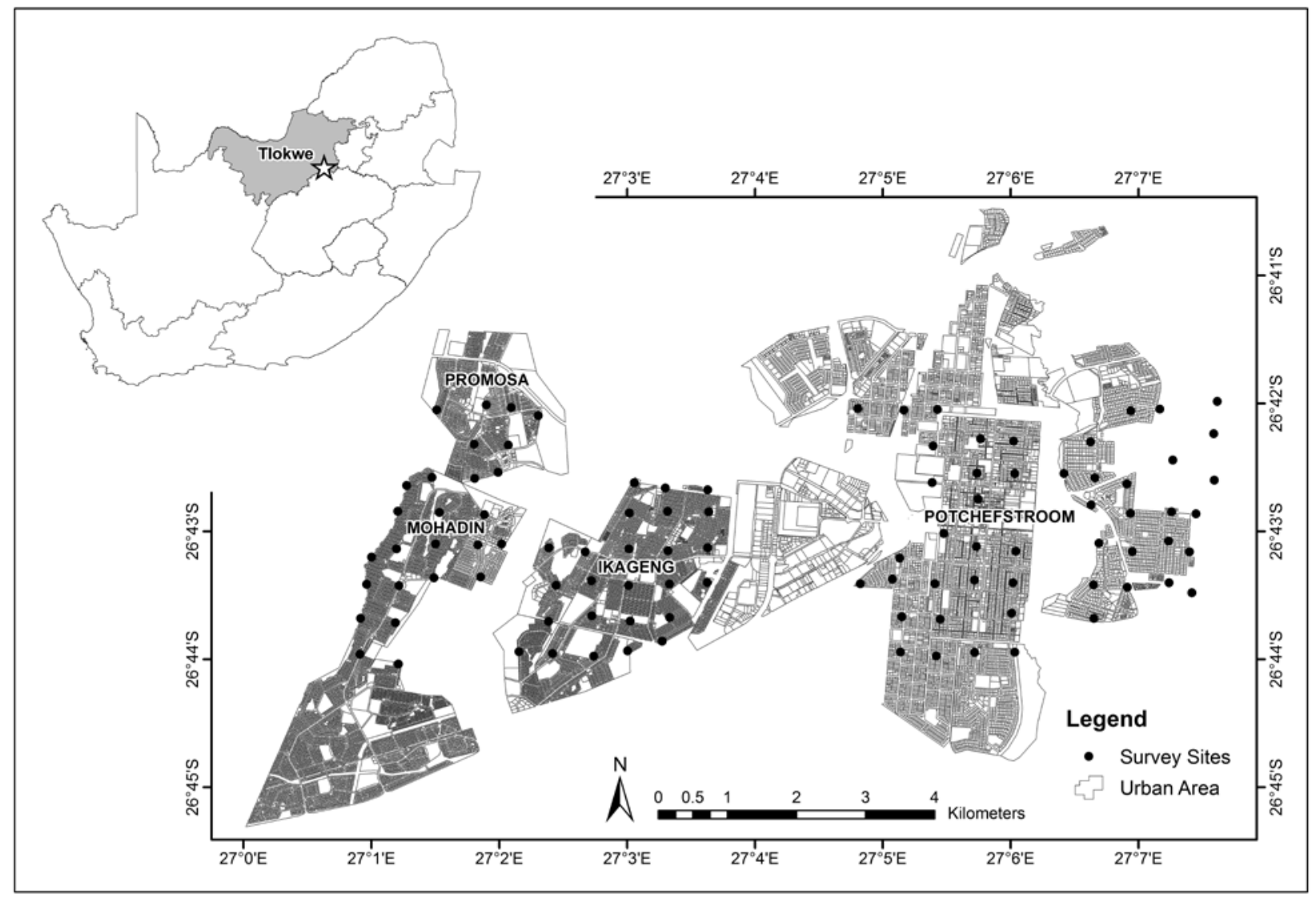

FIGURE 1.-Map of Tlokwe City Municipality (TCM) in South Africa. Survey points indicated by black dots.

mal settlements on the edges of the city. The area has about 140500 inhabitants (WorkWell 2004). The study area falls in the Grassland Biome where the Carletonville Dolomite Grassland, Andesite Mountain Bushveld and the Rand Highveld Grassland vegetation units converge (Mucina \& Rutherford 2006). It is situated at an altitude of $1350 \mathrm{~m}$ and the climate of the region can be described as arid-temperate (Mucina \& Rutherford 2006) with an erratic mean annual rainfall of $593 \mathrm{~mm}$ (mainly in the summer months) and cold, dry winters. Dry years can have annual rainfall as low as 230-300 $\mathrm{mm}$. The mean maximum temperature during the summer months (Dec.-Feb.) is $30.7^{\circ} \mathrm{C}$ with a mean minimum of $0.3^{\circ} \mathrm{C}$ in the winter months (Jun.-Aug.) and frequent frost (Mucina \& Rutherford 2006). The greatest threat to the natural vegetation in the province is the transformation of natural land by agriculture, mining and urbanization (Mangold et al. 2002), threats that are common in areas containing high biodiversity (Kühn et al. 2004; Jha \& Bawa 2006).

\section{METHODS}

For the purpose of this paper, the following definitions were used with regard to species classification as native, indigenous-cultivated, alien or naturalized:

- native-naturally occurring within the study area, usually not cultivated;

- indigenous-cultivated - indigenous to South Africa and not occurring naturally within the study area, but cultivated in gardens;
- naturalized - not indigenous to South Africa, but occurring in the study area where it sustains selfreplacing populations outside of cultivation without direct intervention by people (includes invasive aliens);

- alien cultivated - not indigenous to South Africa and not naturalized in the study area, but cultivated in gardens and including garden hybrid species (includes invasive aliens).

A topographic map of the study area was overlaid with a grid consisting of $500 \times 500 \mathrm{~m}$ squares in ArcView (Environmental Systems Research Institute-ESRI 2006) to identify sampling co-ordinates. Co-ordinates were determined from grid intersects and the exact position of each point in the field was located with a Global Positioning System. A random selection of any domestic garden in its vicinity (no further than $100 \mathrm{~m}$ away) was made. If access to the chosen site was denied (which happened on two occasions), an adjacent garden was sampled. A total of 100 gardens were sampled (Figure 1). Corporate gardens were not included in this study as the management and economic input differ widely from that of domestic gardens.

All the vascular plant species in each garden were noted (presence/absence) to compile a comprehensive list in order to make a qualitative assessment of garden flora. Data from a previous study in the same urban area (Cilliers 1998) were used to compare the garden flora with that of other land use types: natural and semi-natural areas, wetlands, managed areas (parks, pavements and parking areas), roadside verges, vacant lots and railway reserves. In the case 
of domestic gardens, native and indigenous-cultivated species were grouped as indigenous, and cultivated alien and naturalized species were grouped together as alien species, as the data from the previous study (Cilliers 1998) did not distinguish between these groups. Cilliers (1998) sampled the vegetation using the Braun-Blanquet method with plot sizes of $16 \mathrm{~m}^{2}$ for grassland and $100 \mathrm{~m}^{2}$ for woody vegetation to ensure that a representative number of species was detected. Non-random, systematic plantings and high species turnover between gardens due to human preferences, enforced a larger plot size for gardens to ensure a representative sample. The mean plot size for the sampling approach in gardens was determined as a quarter of the mean yard size in the TCM $\left(1648 \mathrm{~m}^{2}\right.$, which includes built-up areas

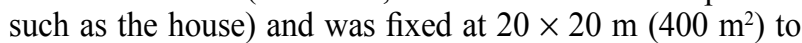
ensure that no yard would be smaller than the plot. Generally, a large proportion of the whole garden (cultivated area) could be chosen as the sample plot. In cases where the gardens (cultivated area) were smaller than the sample plot, paved areas were also included in the sample, as plants often occurred as container plants or weeds.

The indigenous flora of the TCM is well sampled (Bester et al. 2008) and collections in herbaria were sufficient for the identification of indigenous and alien weedy and invasive species that are commonly found. The identification of horticultural plant species was complicated, as these taxa are not well represented in herbaria. Books on gardening and garden plants were used to identify these alien horticultural species (Pienaar 1994, 2000; Joffe 2007; Smith \& Van Wyk 2008).

Cross-referencing was done between our checklist and the South African Red Data List of plants (Raimondo et al. 2009) to determine which threatened species occurred in the domestic gardens of the TCM. Alien invader species were identified from a list of invader species compiled by Henderson (2001), which is based on national legislation (South Africa 1983; Conservation of Agricultural Resources Act of 1983). The distribution of indigenous and naturalized species of South Africa was extracted from Germishuizen et al. (2006). The origin of cultivated alien species as well as the uses of cultivated species was determined from the literature (Van Wyk \& Gericke 2000; Glen 2002; United States Department of Agriculture 2009; Aluka 2010; Hawaiian Ecosystems at Risk 2010). The species accumulation curve was based on 100 randomly shuffled runs, done with the statistical package, Primer 5 (Clarke \& Gorley 2001).

The species grown in the domestic gardens of the TCM were sorted into seven categories: ornamental, weed, food, medicinal, shade, hedge and windbreak. A category for fuel was not included, as any flammable biomass (e.g. firewood, dung, charcoal) serves this purpose for many poor households in the absence of electricity (Millennium Ecosystem Assessment 2003) and therefore no plants were found to be specifically cultivated for this purpose.

\section{RESULTS}

\section{Best represented families}

A total of 145 plant families was recorded for the domestic gardens of the TCM and 56 families (39\%) were represented by only a single species in the study area. The 20 best represented families represent $54 \%$ (455 species) of the total number of species recorded (Table 1). Representation, as indicated here, was determined by the number of species recorded for a given family, regardless of the frequency of occurrence of each species.

Ten of the 20 best represented families in the TCM are on the list (Table 1) of the most species-rich South African families (Germishuizen et al. 2006). Asteraceae, Fabaceae and Iridaceae are the most species-rich South African families and are amongst the top five for the study area. The third and fifth most species-rich South African families (Mesembryanthemaceae and Ericaceae, respectively) were not amongst the best represented garden families. The best represented families contain many garden genera and species that are extensively cultivated throughout the world (e.g. Lamiaceae: Ocimum spp., Lavandula spp., Plectranthus spp.; Rosaceae: Cotoneaster spp., Rosa spp., Prunus spp.; Crassulaceae: Sedum spp., Echeveria spp., Kalanchoe spp.) and many naturalized species (e.g. Fabaceae: Prosopis glandulosa, Robinia pseudoacacia, Medicago laciniata; Solanaceae: Solanum sisymbrifolium, Cestrum elegans; Agavaceae: Agave americana).

Twenty-six families (18\% of all plant families recorded for the TCM) could be classified as exclusively alien as none of their constituent species are indigenous to South Africa (Table 2). These alien families generally comprised less than 10 species, with the exception of Agavaceae with 12 species, which is ranked fifteenth of the twenty best represented families in the TCM (Table 1).

\section{Best represented genera}

In total, 501 plant genera were recorded in the TCM. Of these, two-thirds were represented by only a single species in the TCM. The ten best represented genera

TABLE 1.-Twenty best represented plant families of domestic gardens in the TCM. Superscript enumerators indicate a family's position as one of the 20 largest families in the South African flora (Snyman 2009)

\begin{tabular}{|c|c|c|c|}
\hline Position & Plant family & No. spp. & $\%$ total no. spp. \\
\hline 1 & Asteraceae $^{1}$ & 75 & 9.0 \\
\hline 2 & Poaceae $^{6}$ & 52 & 6.2 \\
\hline 3 & Lamiaceae & 38 & 4.5 \\
\hline 4 & Fabaceae $^{2}$ & 36 & 4.3 \\
\hline 5 & Rosaceae & 33 & 3.9 \\
\hline 6 & Solanaceae & 29 & 3.5 \\
\hline 7 & Crassulaceae $^{17}$ & 21 & 2.5 \\
\hline 8 & Asphodelaceae $^{9}$ & 17 & 2.0 \\
\hline 9 & Cactaceae & 17 & 2.0 \\
\hline 10 & Amaryllidaceae & 15 & 1.8 \\
\hline 11 & Malvaceae ${ }^{16}$ & 15 & 1.8 \\
\hline 12 & Scrophulariaceae $^{7}$ & 14 & 1.7 \\
\hline 13 & Apocynaceae $^{8}$ & 13 & 1.6 \\
\hline 14 & Araceae & 13 & 1.6 \\
\hline 15 & Agavaceae & 12 & 1.4 \\
\hline 16 & Brassicaceae & 11 & 1.3 \\
\hline 17 & Euphorbiaceae ${ }^{14}$ & 11 & 1.3 \\
\hline 18 & Iridaceae $^{4}$ & 11 & 1.3 \\
\hline 19 & Oleaceae & 11 & 1.3 \\
\hline 20 & Verbenaceae & 11 & 1.3 \\
\hline
\end{tabular}


TABLE 2.-Exclusively alien plant families recorded for domestic gardens of TCM and no. species representing each family

\begin{tabular}{lclc}
\hline Alien families & No. spp. & Alien families & No. spp. \\
\hline Agavaceae & 12 & Platanaceae & 2 \\
Caprifoliaceae & 8 & Cannabaceae & 1 \\
Liliaceae sensu stricto & 7 & Capparidaceae & 1 \\
Berberidaceae & 5 & Casuarinaceae & 1 \\
Pinaceae & 5 & Cycadaceae & 1 \\
Aceraceae & 3 & Elaeagnaceae & 1 \\
Alstroemeriaceae & 3 & Ginkgoaceae & 1 \\
Bromeliaceae & 3 & Juglandaceae & 1 \\
Saxifragaceae & 3 & Punicaceae & 1 \\
Cannaceae & 2 & Saururaceae & 1 \\
Fagaceae & 2 & Simaroubaceae & 1 \\
Magnoliaceae & 2 & Theaceae & 1 \\
Marantaceae & 2 & Tropaeolaceae & 1 \\
\hline
\end{tabular}

constituted nine percent of the total number of recorded species (Table 3). Only three of the best represented genera (Asparagus, Cyperus and Tradescantia) belong to families not included amongst the 20 best represented for the study area (Asparagaceae, Cyperaceae and Commelinaceae). Thirty-four of the 78 species (44 $\%$ ) belonging to the ten best represented genera of urban domestic gardens in the TCM are alien to South Africa.

TABLE 3.-Best represented genera in domestic gardens of TCM and no. species representing each

\begin{tabular}{llc}
\hline Genera & Family & No. spp. \\
\hline Solanum & Solanaceae & 12 \\
Aloe & Asphodelaceae & 10 \\
Eragrostis & Poaceae & 9 \\
Salvia & Lamiaceae & 9 \\
Asparagus & Asparagaceae & 8 \\
Acacia & Fabaceae & 7 \\
Cyperus & Cyperaceae & 6 \\
Plectranthus & Lamiaceae & 6 \\
Prunus & Rosaceae & 6 \\
Tradescantia & Commelinaceae & 6 \\
\hline
\end{tabular}

\section{Most frequent species}

A total of 835 species was recorded from the domestic gardens of the TCM, of which 235 were recorded only once and most of them were alien (70 \%). The species accumulation curve for these 100 sample plots had not reached an asymptote (Figure 2), suggesting that the species will further increase as more gardens are sampled.

The 20 plant species that occurred most frequently were all present in more than half of the sampled gardens (Table 4). Pennisetum clandestinum, as the most favoured lawn grass, was the highest ranked species as it occurred in all but one of the gardens (99\%). Another grass species, Cynodon dactylon, had the second highest frequency. Three herbaceous species (Euphorbia prostrata, Conyza bonariensis and Guilleminea densa), which are commonly considered as naturalized garden weeds, made up the rest of the top five. Cynodon dactylon is the only native species amongst the top five most frequent species and it is also regarded as a declared weed (Henderson 2001). Ten of the recorded 20 most frequent species are naturalized in South Africa, compared to the seven cultivated (indigenous and alien) and three native species. The best-represented families among the twenty most frequent species are the Poaceae (five species) and Asteraceae (three species).

TABLE 4.-Twenty most frequently recorded species from domestic gardens of TCM

\begin{tabular}{|c|c|c|c|}
\hline Species & Families & Origin & $\%$ plots \\
\hline Pennisetum clandestinum* & Poaceae & $\mathrm{CA}$ & 99 \\
\hline Cynodon dactylon & Poaceae & $\mathrm{IC}$ & 84 \\
\hline Euphorbia prostrata* & Euphorbiaceae & $\mathrm{N}$ & 79 \\
\hline Conyza bonariensis* & Asteraceae & $\mathrm{N}$ & 76 \\
\hline Guilleminea densa* & Amaranthaceae & $\mathrm{N}$ & 72 \\
\hline Portulaca oleracea* & Portulacaceae & $\mathrm{N}$ & 69 \\
\hline Dichondra micrantha* & Convolvulaceae & $\mathrm{CA}$ & 66 \\
\hline Urochloa panicoides & Poaceae & Nat & 66 \\
\hline Cynodon hirsutus & Poaceae & Nat & 65 \\
\hline Ligustrum lucidum* & Oleaceae & $\mathrm{CA}$ & 63 \\
\hline Oxalis corniculata* & Oxalidaceae & $\mathrm{N}$ & 62 \\
\hline Rosa chinensis* & Rosaceae & $\mathrm{CA}$ & 61 \\
\hline Alternanthera pungens* & Amaranthaceae & $\mathrm{N}$ & 59 \\
\hline Euphorbia hirta* & Euphorbiaceae & $\mathrm{N}$ & 59 \\
\hline Sonchus oleraceus* & Asteraceae & $\mathrm{N}$ & 59 \\
\hline Bidens bipinnata* & Asteraceae & $\mathrm{N}$ & 56 \\
\hline Chlorophytum comosum & Anthericaceae & IC & 56 \\
\hline Prunus persica* & Rosaceae & $\mathrm{CA}$ & 56 \\
\hline Amaranthus viridis* & Amaranthaceae & $\mathrm{N}$ & 55 \\
\hline Eragrostis lehmanniana & Poaceae & Nat & 52 \\
\hline
\end{tabular}

\section{Endemic species}

A list of species endemic to South Africa was recorded for the domestic gardens of the TCM (Table 5). It serves as confirmation of the contribution that domestic gardens make towards the conservation of unique plant species. In total, 61 endemic species were recorded, all of which are commonly cultivated, except for three species that are normally only found as weeds in gardens (Pienaar 1994; Pienaar 2000; Germishuizen et al. 2006). Tulbaghia violacea was the most commonly cultivated South African endemic as it occurred in $30 \%$ of the sampled gardens. Portulaca grandiflora and Sida spinosa were both also commonly cultivated $(27 \%)$. Nine other endemic species were present in 10 $\%$ or more of the sample plots. In contrast, 49 endemic species occurred in less than $10 \%$ of the plots, with 19 found only once.

\section{Endangered and protected species}

Eighteen species that have a threat status assigned according to the South African National Red Data List (Raimondo et al. 2009), were recorded from domestic gardens in the TCM (Table 6). These include species listed as EN: Endangered (4); VU: Vulnerable (4); NT: Near Threatened (3); Rare (2); and Declining (5). The 
most common of these threatened species were Clivia miniata (VU) and Dietes bicolor (Rare), which occurred in more than $10 \%$ of the sampled gardens. The occurrence of the remaining 16 species was lower (Table 6).

\section{Useful plants}

The utilization of plants as food, natural healing remedies, construction material and for other benefits is as

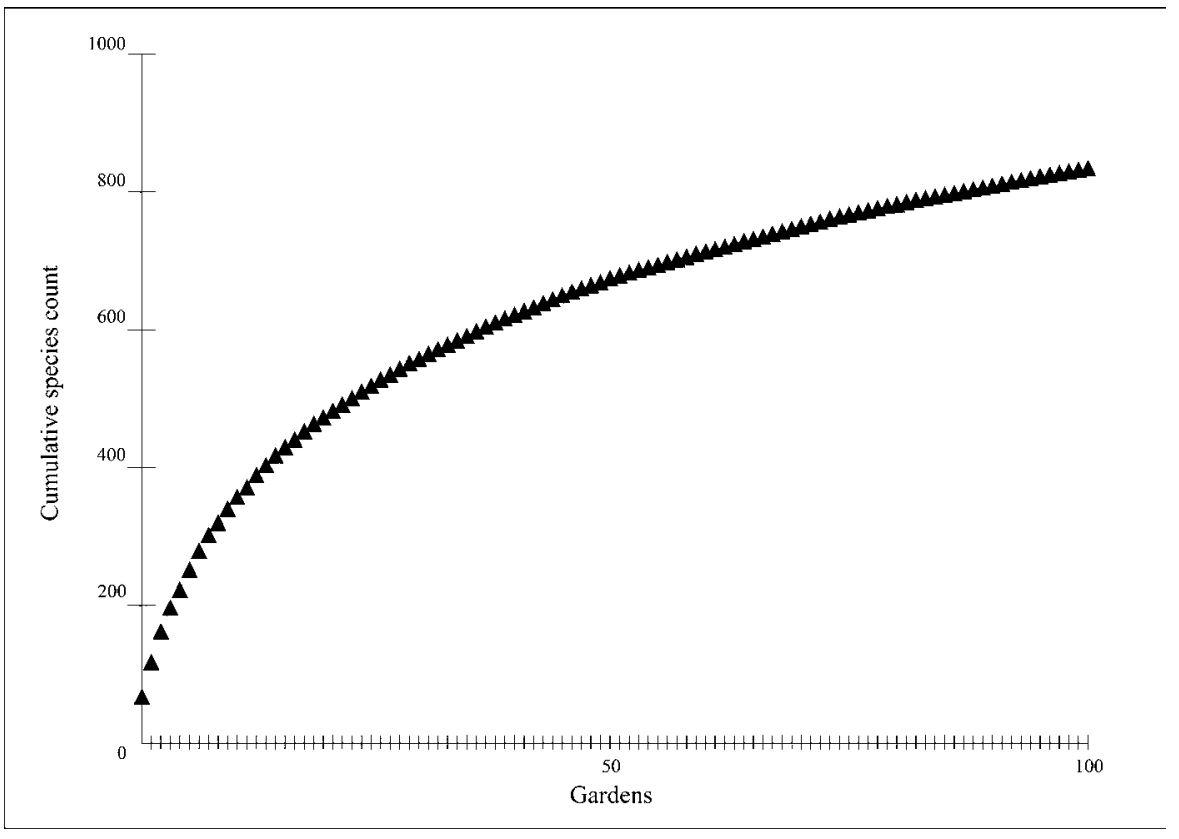

FIGURE 2.-Species accumulation curve for 100 domestic gardens in TCM.

TABLE 5.- South African endemic species recorded from domestic gardens of TCM

\begin{tabular}{|c|c|c|c|c|c|}
\hline Species & Origin & $\%$ plots & Species & Origin & $\%$ plots \\
\hline Tulbaghia violacea & $\mathrm{C}$ & 30 & Anisodontea elegans & $\mathrm{C}$ & 2 \\
\hline Portulaca grandiflora & $\mathrm{C}$ & 27 & Crassula capitella & $\mathrm{C}$ & 2 \\
\hline Sida spinosa & $\mathrm{N}$ & 27 & Crassula tetragona & $\mathrm{C}$ & 2 \\
\hline Tulbaghia simmleri & $\mathrm{C}$ & 22 & Cussonia paniculata & $\mathrm{C}$ & 2 \\
\hline Crassula ovata & $\mathrm{C}$ & 19 & Encephalartos natalensis & $\mathrm{C}$ & 2 \\
\hline Euryops chrysanthemoides & $\mathrm{C}$ & 16 & Felicia amelloides & $\mathrm{C}$ & 2 \\
\hline Strelitzia alba & $\mathrm{C}$ & 12 & Haworthia cymbiformis & $\mathrm{C}$ & 2 \\
\hline Aptenia cordifolia & $\mathrm{C}$ & 11 & Lampranthus glaucus & $\mathrm{C}$ & 2 \\
\hline Cyperus textilis & $\mathrm{C}$ & 11 & Nemesia strumosa & $\mathrm{C}$ & 2 \\
\hline Dietes bicolor & $\mathrm{C}$ & 11 & Podocarpus henkelii & $\mathrm{C}$ & 2 \\
\hline Lampranthus roseus & $\mathrm{C}$ & 10 & Podranea ricasoliana & $\mathrm{C}$ & 2 \\
\hline Ledebouria socialis & $\mathrm{C}$ & 10 & Aloe brevifolia & $\mathrm{C}$ & 1 \\
\hline Chondropetalum tectorum & $\mathrm{C}$ & 9 & Aloe tenuior & $\mathrm{C}$ & 1 \\
\hline Strelitzia reginae & $\mathrm{C}$ & 9 & Carpobrotus edulis & $\mathrm{C}$ & 1 \\
\hline Dimorphotheca ecklonis & $\mathrm{C}$ & 8 & Crassula multicava & $\mathrm{C}$ & 1 \\
\hline Pelargonium peltatum & $\mathrm{C}$ & 8 & Cyrtanthus elatus & $\mathrm{C}$ & 1 \\
\hline Agapanthus africanus & $\mathrm{C}$ & 7 & Encephalartos horridus & $\mathrm{C}$ & 1 \\
\hline Haworthia fasciata & $\mathrm{C}$ & 7 & Geranium incanum & $\mathrm{C}$ & 1 \\
\hline Dietes grandiflora & $\mathrm{C}$ & 5 & Haemanthus albiflos & $\mathrm{C}$ & 1 \\
\hline Gasteria bicolor & $\mathrm{C}$ & 5 & Haworthia reinwardtii & $\mathrm{C}$ & 1 \\
\hline Gnaphalium nelsonii & $\mathrm{N}$ & 5 & Lampranthus glaucoides & $\mathrm{C}$ & 1 \\
\hline Ornithogalum thyrsoides & $\mathrm{C}$ & 5 & Melianthus elongatus & $\mathrm{C}$ & 1 \\
\hline Zantedeschia pentlandii & $\mathrm{C}$ & 5 & Oxalis lanata & $\mathrm{C}$ & 1 \\
\hline Lampranthus blandus & $\mathrm{C}$ & 4 & Pelargonium reniforme & $\mathrm{C}$ & 1 \\
\hline Begonia homonyma & $\mathrm{C}$ & 3 & Plectranthus saccatus & $\mathrm{C}$ & 1 \\
\hline Coleonema pulchellum & $\mathrm{C}$ & 3 & Scabiosa africana & $\mathrm{C}$ & 1 \\
\hline Ehretia rigida & $\mathrm{N}$ & 3 & Senecio articulatus & $\mathrm{C}$ & 1 \\
\hline Lampranthus aureus & $\mathrm{C}$ & 3 & Senecio rowleyanus & $\mathrm{C}$ & 1 \\
\hline Ocimum serratum & $\mathrm{C}$ & 3 & Senecio scaposus & $\mathrm{C}$ & 1 \\
\hline Plectranthus hilliardiae & $\mathrm{C}$ & 3 & Ursinia chrysanthemoides & $\mathrm{C}$ & 1 \\
\hline Aloe striatula & $\mathrm{C}$ & 2 & & & \\
\hline
\end{tabular}

C, cultivated; $\mathrm{N}$, natural. 
TABLE 6.- Red Data species recorded in domestic gardens of TCM (Raimondo et al. 2009)

\begin{tabular}{lcc}
\hline Species & National status & No. plots \\
\hline Begonia homonyma & $\mathrm{EN}$ & 3 \\
Lampranthus aureus & $\mathrm{EN}$ & 3 \\
Encephalartos horridus & $\mathrm{EN}$ & 1 \\
Encephalartos lebomboensis & $\mathrm{EN}$ & 1 \\
Clivia miniata & $\mathrm{VU}$ & 27 \\
Crinum moorei & $\mathrm{VU}$ & 5 \\
Zantedeschia pentlandii & $\mathrm{VU}$ & 5 \\
Lampranthus glaucus & $\mathrm{VU}$ & 2 \\
Haworthia fasciata & $\mathrm{NT}$ & 7 \\
Encephalartos natalensis & $\mathrm{NT}$ & 2 \\
Nemesia strumosa & $\mathrm{NT}$ & 2 \\
Dietes bicolor & Rare & 11 \\
Freylinia tropica & Rare & 2 \\
Crinum bulbispermum & Declining & 6 \\
Eucomis autumnalis & Declining & 6 \\
Crinum macowanii & Declining & 2 \\
Hypoxis hemerocallidea & Declining & 2 \\
Acacia erioloba & Declining & 1 \\
\hline
\end{tabular}

EN, Endangered; NT, Near Threatened; VU, Vulnerable.

old as humanity itself and an important part of South Africa's cultural heritage (Van Wyk et al. 1997; Van Wyk \& Gericke 2000). Most of the plant species (61\%) were cultivated in domestic gardens solely for ornamen- tal purposes (Figure 3). Frequent species in this group included Rosa chinensis and Agapanthus praecox. The second largest group was the weeds (16\%), with Cynodon dactylon and Euphorbia prostrata as frequent species. A further $9 \%$ of the species were classified as food plants on account of their edible leaves, tubers, fruits or seeds. Medicinal plants accounted for $7 \%$ of all the species, while $5 \%$ were regarded as shade trees. Hedges and windbreaks did not make a considerable contribution in terms of species richness.

\section{Origin of indigenous-cultivated species}

Most of the species found in the domestic gardens of the TCM do not occur naturally in South Africa (72.2 $\%$ of the garden flora). The remaining $27.8 \%$ of the recorded garden flora consisted of 232 native and indigenous-cultivated species (Germishuizen et al. 2006). The number of indigenous species in each of six geographical groups in South Africa is shown in Figure 4. Widespread species, that have fewer specific environmental preferences, contributed greatly towards the cultivated garden flora, with 122 species recorded from more than eight of the 13 regions specified in Germishuizen et al. (2006). Thereafter, most of the cultivated species (69) were contributed by the flora of the Eastern Cape and KwaZulu-Natal (southeastern provinces). The other four regions all made smaller contributions to the domestic garden flora of the TCM (Figure 4).
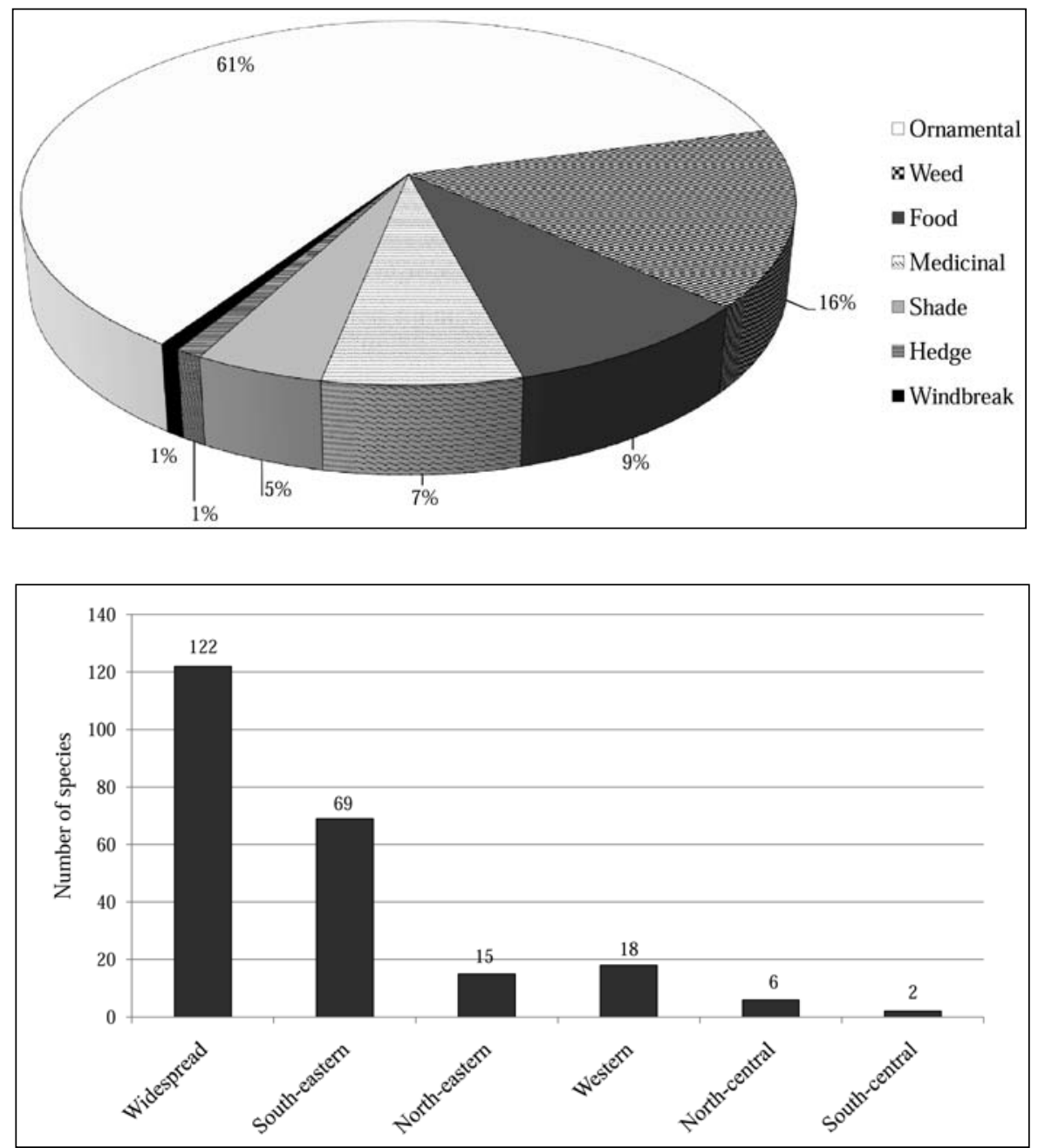

FIGURE 3.-Contribution of urban flora towards seven useful plant categories of domestic gardens in TCM.
FIGURE 4.-Main geographical origin of indigenous-cultivated species that were recorded for domestic gardens in TCM. South-central (Free State, Lesotho); Northcentral (North-West Province, Limpopo, Botswana); Western (Western Cape, Northern Cape, Namibia); North-eastern (Mpumalanga, Gauteng, Swaziland), South-eastern (KwaZulu-Natal, Eastern Cape); Widespread, defined as occurring naturally in eight or more regions. 


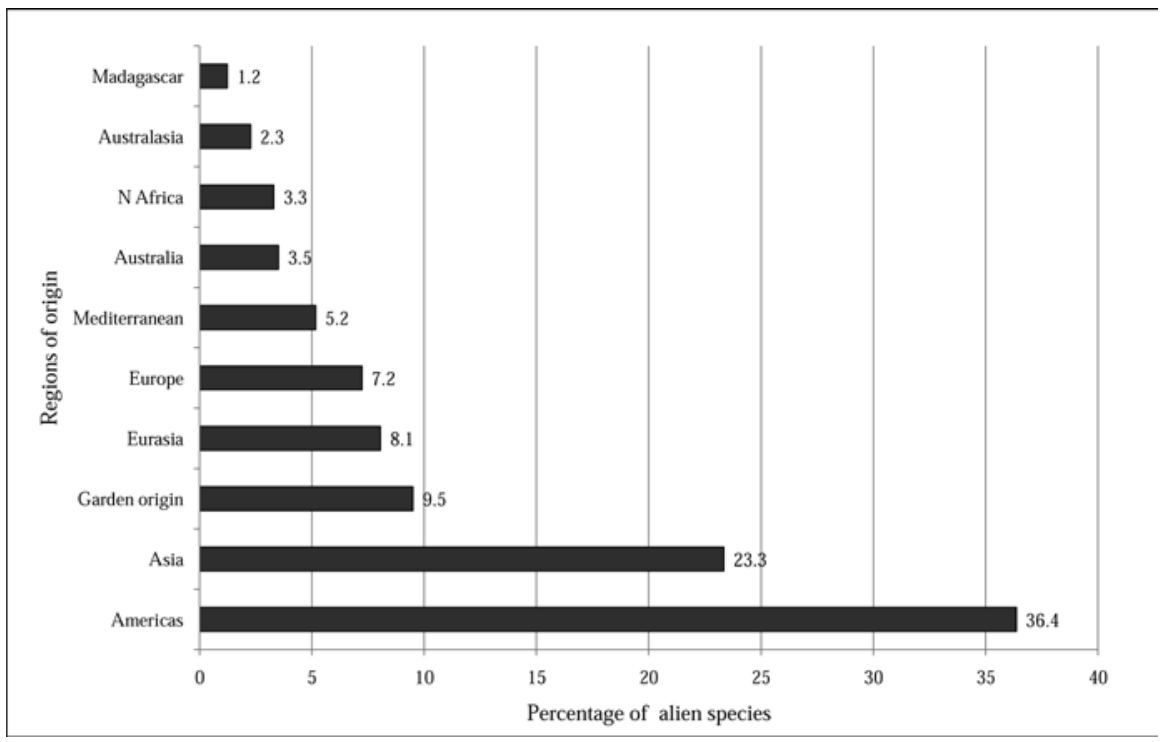

FIGURE 5.- Ten regions of origin of alien cultivated and naturalized alien species recorded for domestic gardens in TCM.
TABLE 7.- Three most frequent invasive species recorded for each declared category of invasiveness and proposed invaders. No. species recorded for each category in brackets

\begin{tabular}{lc}
\hline Category 1: declared weeds (32) & No. occurrences \\
\hline Canna $\times$ generalis & 43 \\
Araujia sericifera & 23 \\
Nerium oleander & 17 \\
\hline Category 2: declared invaders (12) & No. occurrences \\
\hline Pennisetum clandestinum & 99 \\
Cynodon dactylon & 84 \\
Robinia pseudoacacia & 15 \\
\hline Category 3: declared invaders (36) & No. occurrences \\
\hline Ligustrum lucidum & 63 \\
Ipomoea purpurea & 35 \\
Nephrolepis exaltata & 32 \\
\hline Proposed invaders (8) & No. occurrences \\
\hline Celtis sinensis & 38 \\
Celtis australis & 9 \\
Duranta erecta & 5 \\
\hline
\end{tabular}

Category 1: prohibited in South Africa, must be eradicated where possible; Category 2: planting only allowed under controlled conditions in demarcated areas, trading only with permits; Category 3: no further plantings and no trade allowed (Henderson 2001).

\section{Origin of naturalized and cultivated alien species}

No information was available regarding the origin of 65 of the naturalized and cultivated alien species, and 31 species originated from more than one region. The remaining 484 naturalized and cultivated alien species could be grouped according to regions of common origin (Figure 5). More than a third $(36.4 \%)$ of the alien horticultural plant species found in the domestic gardens of the TCM was originally introduced from the Americas (North, Central and/or South America). Asia was the second largest contributor to the alien horticultural flora, as $23.3 \%$ of the species originate from there. Hybrids that originated in gardens also made a significant contribution of $9.5 \%$.

\section{Invasive species}

Apart from the substantial utilization, maintenance and conservation of biodiversity found in gardens, there are some unforeseen consequences, such as the occur- rence of invasive alien species. In the domestic gardens of the TCM, 88 declared invader and weed species were found (Table 7) (Henderson 2001). There were 32 Category 1 declared weeds, which comprise the most severe type of invasive species. Canna $\times$ generalis formed part of this group and it occurred in $43 \%$ of gardens. Pennisetum clandestinum and Cynodon dactylon, which have shown the highest occurrences of all, were some of the species classified as Category 2 declared invaders. Category 3 declared invaders had the highest number of species (36) and included, amongst others, Ligustrum lucidum in more than $60 \%$ of the surveyed gardens. Celtis sinensis $(38 \%)$, from the list of proposed invaders, was found to be the most frequent species in this category.

\section{Growth forms}

Most of the species found in the domestic gardens of the TCM were forbs (341) (Figure 6). Euphorbia prostrata and Guilleminea densa were the most frequent herbaceous species occurring respectively in $79 \%$ and $72 \%$ of sample plots. The second most frequent growth form was shrubs (173 species) with frequent species such as Rosa chinensis and Ficus carica, followed by trees (131 species), of which the most frequent representative was the popular hedge species Ligustrum lucidum. Prunus persica was found to be the second most frequent tree species, as it is commonly cultivated for its edible fruit. Succulents, geophytes and graminoids were all represented by a lower, but relatively similar number of species with ferns being the smallest represented group.

\section{Total species diversity}

The total number of species and the numbers of indigenous and alien species of different land use types were compared (Figure 7). Two distinct floristic differences are evident between domestic gardens and the other land use types. The first is the substantially higher total number of species (or gamma diversity) of domestic gardens when compared to the other land use types. The other difference is the inverted relationship of indigenous and alien species in domestic gardens when compared to the other land use types. Domestic gardens contained almost twice as many alien as indigenous species. 


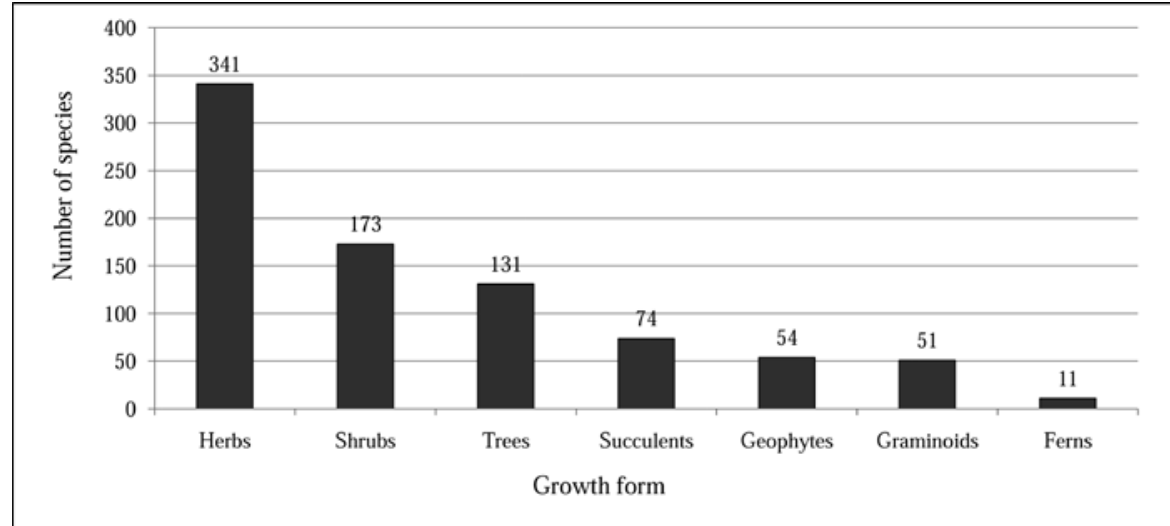

DISCUSSION

\section{Most frequent taxa}

Urban areas are characterized as heterogeneous and highly dynamic environments (Rebele 1994), a phenomenon that is also observed within domestic gardens of residential areas (Mathieu et al. 2007). The gamma diversity of plant species encountered in the 100 sampled domestic gardens of the TCM (835 species) is in accordance with results from other studies, e.g. 973 species in Lauris, France, from 120 gardens (Marco et al. 2008) and 1166 species in Sheffield, United Kingdom, from 61 gardens (Smith et al. 2006). However, the fact that 235 species were recorded only once is indicative of the high species turnover between gardens, and is consistent with the gardens of Sheffield (Thompson et al. 2003). The lack of saturation of the species accumulation curve is also in accordance with results from other domestic garden studies (Smith et al. 2006) and indicates that the number of plant species would continue to increase if more sample sites were included in the survey. According to Smith et al. (2006), the theoretical limit for the garden species pool is set by the number of species available in the horticultural trade.

All the most frequent garden genera are well represented in the South African natural flora, except for
Prunus and Tradescantia (Germishuizen et al. 2006). Many species from the most frequent genera, such as Solanum, Aloe and Salvia, are popular ornamental species or declared weeds, which may explain to a certain extent the frequent occurrence of these genera in gardens. Despite a high number of species from these genera being alien to South Africa (44\%), none of the most frequent genera belong to alien families. This means that the alien species have a close affinity with South African indigenous species at family level (Germishuizen et al. 2006). Of the 20 most frequent species, most were naturalized weeds rather than cultivated species. These naturalized species may originally have been horticultural subjects that escaped from gardens into the natural surroundings (Hodkinson \& Thompson 1997; Siebert et al. 2010). Species belonging to alien plant families are cultivated mostly for their high ornamental value, e.g. Cordyline australis, Abelia $\times$ grandiflora, Aspidistra elatior and Nandina domestica.

\section{Endemic and endangered species}

Endemic and endangered species represent only a small portion of the garden flora, but, however small the contribution of a few gardens may be towards the protection of such species, its collective effort across an entire urban ecosystem and also globally holds tremen-

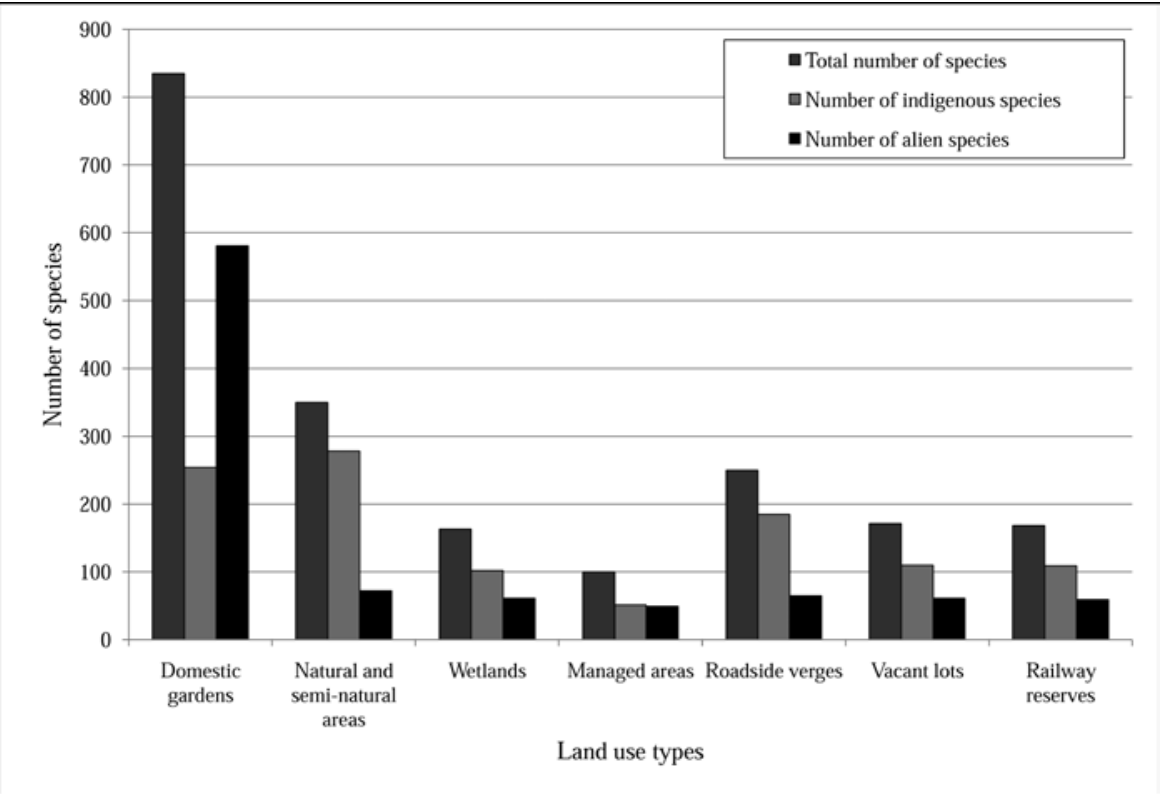

FIGURE 7.-Comparison of total species, indigenous species (including native species) and alien species (including naturalized species) for land use types of TCM (gamma diversity). 
dous potential (Savard et al. 2000; Gaston et al. 2005). However, the cultivation of these species takes place for their utilitarian value and not necessarily with conservation in mind. As perceptions of what is considered useful can change over time, these plant species of conservation concern may be replaced with something new. The presence of these rare and endangered species in domestic gardens highlights the role that such land use types can fulfil in the conservation of indigenous biodiversity, albeit a somewhat vulnerable niche. Through interaction of gardens with other types of greenspace in close vicinity within the urban environment, better support of biodiversity is possible - a concept described by Colding (2007) as 'ecological land-use complementation'. This means that more indigenous species can be supported in terms of nutrition, space and water resources by the combined patches of the entire urban green infrastructure, which stresses the importance of proper planning of urban development. Furthermore, the conservation resources that already exist can be utilized better in protecting not only endangered, but also abundant indigenous species (Hamilton 1999).

\section{Useful plants}

Despite the high proportion of species originating from Asia and the Americas, the culture of gardening in Potchefstroom is predominantly European (Cilliers 2010), which has influenced local cultures across socioeconomic classes (Lubbe et al. 2010), resulting in the high frequency of ornamental plant species in most gardens of the city. Inhabitants of Ganyesa, a small, rural village in the North-West Province, also cultivate many ornamental species - an indication that even poorer, more traditional communities regard aesthetics as important (Cilliers 2010). Weeds, the second largest group (Figure 3 ), are not favoured by gardeners because of their occurrence in unwanted locations (Henderson 2001). However, these plants are almost always present in gardens and contribute towards the ecological environment within the garden. Food plants did not contribute as significantly to the diversity of the total flora (9\%) of the TCM gardens as would be expected. For instance, in Ganyesa almost $28 \%$ of plant species were classified as food plants (Cilliers 2010). Molebatsi et al. (2010) have shown that the Batswana communities in the rural areas harboured a greater number of useful, indigenous species in their home gardens. This is an indication of the dependence of poorer communities on utility gardens for their livelihoods. The other categories (medicinal, shade, hedge and windbreak species) all made very small contributions to the diversity of the garden flora. Some of the species that are cultivated locally as hedges, however, occurred in many gardens (Ligustrum lucidum, $63 \%$; Rosa banksiae, $19 \%$ ), indicating that a low percentage contribution of a plant use category (Figure 3) may underestimate the importance of its constituent species.

\section{Species distribution}

Species that are widespread throughout and occur naturally in South Africa (native and indigenous-cultivated species) were most common in gardens, such as the tree Acacia karroo, and grasses Cynodon dactylon and Eragrostis lehmanniana. Species originating from the south- eastern provinces were also commonly cultivated, for example Chlorophytum comosum, Tulbaghia violacea and Clivia miniata. Van Jaarsveld (2001) argued that species from the Eastern Cape are especially well suited for gardening almost anywhere in the world, because they are extremely tolerant to disturbance, wide temperature ranges and can endure both drought and excessively wet conditions. Fewer species from the other regions of South Africa (for example fynbos species) are found in gardens, as they may not always be as tolerant of the dynamic and ever-changing conditions in gardens. The fact that indigenous species play an important role in cultivation practices is partly ascribed to nurseries promoting such plantings in gardens. All three of the major nurseries in Potchefstroom keep $20-30 \%$ of indigenous stock for cultivation and recommend these above alien horticultural species (J. du Toit 2010, A. Grobler 2010, I. Scheepers 2010 pers. comm.). In many cases, however, customers purchase the more colourful or hardy alien horticultural species, of which there is normally a greater variety available.

Plant species from similar climates are adapted to specific environmental conditions, such as temperature ranges and frost resistance, and should thus be able to survive such conditions elsewhere. Commonalities between the climate of the country of origin of cultivated alien species and the South African Highveld climate could be the reason why the Americas and Asia were the largest contributors to the alien horticultural flora of the TCM, indicating that plant species from these regions may be best suited for the local climatic conditions, and even hardier than most indigenous species. Apart from hardiness and suitability for cultivation, these cultivated alien species also share another important characteristic - ornamental or food value - that makes them popular for cultivation. The garden hybrids also made a substantial contribution to the garden flora, suggesting that these taxa are already adapted to the environmental conditions in domestic gardens.

\section{Invasive species}

South Africa is regarded as a country threatened by invasive alien plants, with 1226 alien taxa occurring within its borders (Richardson et al. 2005). Many of these alien species possess the potential to escape from cultivation in gardens to form self-sustaining natural populations (Sullivan et al. 2005). This may have detrimental effects on the survival and existence of indigenous vegetation and biodiversity (Pimentel et al. 2000; Richardson \& Van Wilgen 2004). The high number of alien invasive species found in domestic gardens of the TCM confirmed that this problem has its origin in ecosystems created by man where sources of alien invasive species are maintained. Most of the invasive species found in domestic gardens either were cultivated extensively in the past, although they may not be commercially available anymore, e.g. Ligustrum lucidum, or are still cultivated and available today (Canna $\times$ generalis, Celtis sinensis and Pennisetum clandestinum). The fact that these species are still cultivated could be an indication that they may become even more problematic in the future and that more cultivated species have the potential to spread into the natural environment (Aronson et al. 2007). However, due to the low occurrence of most 
of the cultivated invasive species in gardens, it is less likely that these species will spread outside of cultivation. This information on the presence and abundance of invasive species in domestic gardens can be incorporated into preventative measures and eradication plans for the future.

\section{Species diversity}

The higher gamma diversity of domestic gardens when compared to other land use types is further proof of the heterogeneous nature of urban areas and gardens. In the Phoenix-Arizona metropolis, Hope et al. (2003) found that the city had much higher gamma diversity than the surrounding desert as a result of the introduced alien vegetation that has replaced the indigenous species. The high gamma diversity of urban domestic gardens is the result of the diverse species pool that gardeners can choose from for cultivation purposes in a variety of habitat types. Plant diversity is generally viewed as an indication and determinant of overall biodiversity, influencing all related biota (Matson et al. 1997) and the green spaces in urban areas are thus of critical importance for all that are living in these environments.

More alien than indigenous species are cultivated in domestic gardens because cultivation practices promote the planting of hardy and aesthetic alien species that can be imported from all over the world (Thompson et al. 2003; Kühn et al. 2004), simultaneously contributing to high species diversity. Gardens are continually supplied with nutrients and water, thus diminishing the constraints of survival associated with natural areas and thereby increasing the number of species that can exist in a limited environment (Hope et al. 2003; Niinemets $\&$ Peñuelas 2008). Species that would otherwise not survive in local habitats and climates are thus able to survive.

\section{CONCLUSION}

The data presented here is a snapshot of the entire garden flora of a southern African city - a moment in time of a very dynamic and complex system. Nevertheless, it provides a broad picture of the state of the garden flora. As there is very little such descriptive data available, especially for developing countries, this paper contributes to the pool of knowledge necessary to understand urban biodiversity, and urban ecosystems as a whole, more effectively.

Domestic gardens contribute to the plant diversity of the urban ecosystem, which forms the basis of the provision of several ecosystem goods and services. Furthermore, gardens have enormous potential to maintain indigenous diversity and threatened species, albeit on a small scale, in every garden. On the other hand, with most of the species cultivated in gardens being alien, it holds the potential to produce even more invasive species that could harm our natural ecosystems and indigenous vegetation. Considering both the benefits of garden vegetation and the possible threat that it poses to our natural heritage, much more knowledge on the ecological functioning of gardens is necessary to fully understand their features and allow authorities to manage the natural environment in cities sensibly and optimize its potential for sustainability.

\section{REFERENCES}

ALBERTI, M. 2005. The effects of urban patterns on ecosystem function. International Regional Science Review 28: 168-192.

ALUKA. 2010. African plants (accessed 3 Feb. 2010). http://www.aluka.org/page/content/plants.jsp.

ARONSON, M.F.J., HANDEL, S.N. \& CLEMANTS, S.E. 2007. Fruit type, life form and origin determine the success of woody plant invaders in an urban landscape. Biological Invasions 9: 465-475.

BESTER, S.P., STEYN, H.M. \& KOEKEMOER, M. 2008. National plant collecting programme: is it worth the trouble? Progress on collection in Tankwa Karoo and Namaqua National Parks. South African Journal of Botany 74: 385.

BOLUND, P. \& HUNHAMMAR, S. 1999. Ecosystem services in urban areas. Ecological Economics 29: 293-301.

CILLIERS, S.S. 1998. Phytosociological studies of urban open spaces in Potchefstroom, North West Province, South Africa. Ph.D. thesis, PU for CHE, Potchefstroom.

CILLIERS, S.S. 2010. Social aspects of urban biodiversity: overview. In N. Müller, P. Werner \& J. Kelcey, Urban biodiversity and design-implementing the convention on biological diversity in towns and cities: 81-100. Wiley-Blackwell Publishing, Oxford.

CLARKE, K.R. \& GORLEY, R.N. 2001. PRIMER v.5: User manual/ tutorial. Primere Publishers, Plymouth.

COLDING, J. 2007. 'Ecological land-use complementation' for building resilience in ecosystems. Landscape and Urban Planning 81: 46-55.

ENVIRONMENTAL SYSTEMS RESEARCH INSTITUTE (ESRI). 2006. ArcView 9.2. www.esri.com. Redlands, USA.

GASTON, K.J., WARREN, P.H., THOMPSON, K. \& SMITH, R.M. 2005. Urban domestic gardens (IV): the extent of the resource and its associated features. Biodiversity and Conservation 14: 3327-3349.

GERMISHUIZEN, G., MEYER, N.L., STEENKAMP, Y. \& KEITH, M. (eds). 2006. A checklist of South African plants. Southern African Botanical Diversity Network Report No. 41. SABONET, Pretoria.

GLEN, H.F. 2002. Cultivated plants of southern Africa. Jacana, Johannesburg.

GODEFROID, S. \& KOEDAM, N. 2007. Urban plant species patterns are highly driven by density and function of built-up areas. Landscape Ecology 22: 1227-1239.

HAMILTON, H.R. 1999. The case for abundant species management. Human Dimensions of Wildlife 4: 74-85.

HAWAIIAN ECOSYSTEMS AT RISK. 2010. Hawaiian Ecosystems at Risk Project. http://www.hear.org/ (accessed 3 Feb. 2010).

HENDERSON, L. 2001. Alien weeds and invasive plants. Agricultural Research Council, Pretoria.

HODKINSON, D.J. \& THOMPSON, K. 1997. Plant dispersal: the role of man. Journal of Applied Ecology 34: 1484-1496.

HOPE, D., GRIES, C., CASAGRANDE, D., REDMAN, C.L., GRIMM, N.B. \& MARTIN, C. 2006. Drivers of spatial variation in plant diversity across the central Arizona-Phoenix system. Society and Natural Resources 19: 101-116.

HOPE, D., GRIES, C., ZHU, W., FAGAN, W.F., REDMAN, C.L., GRIMM, N.B., NELSON, A.L., MARTIN, C. \& KINZIG, A. 2003. Socio-economics drive urban plant diversity. Proceedings of the National Academy of Sciences 100: 8788-8792.

ISAACSON, R.T. 2004. The Anderson Horticultural Library's source list of plants and seeds: a completely revised listing of 2000-2003 catalogues, edn 6. Anderson Horticultural Library, Chanhassen, USA.

JHA, S. \& BAWA, K.S. 2006. Population growth, human development, and deforestation in biodiversity hotspots. Conservation Biology 20: 906-912.

JOFFE, P. 2007. Skeppende tuinmaak met inheemse plante: 'n SuidAfrikaanse gids. Briza Publications, Pretoria.

KÜHN, I., BRANDL, R. \& KLOTZ, S. 2004. The flora of German cities is naturally species rich. Evolutionary Ecology Research 6: 749-764.

LUBBE, C.S., SIEBERT, S.J. \& CILLIERS, S.S. 2010. Political legacy of South Africa affects the plant diversity patterns of urban domestic gardens along a socio-economic gradient. Scientific Research and Essays, 5: 2900-2910. 
MACAULAY, D., BUCHANAN, N., BURTON, R. \& MURPHY, M 2009. RHS plant finder 2009-2010. Dorling Kindersley, London.

MANGOLD, S., MOMBERG, M. \& NEWBERY, R. 2002. Biodiversity and conservation. In S. Mangold \& M. Kalule-Sabiti, North West Province State of the Environment Report: 1-106. Department of Environmental Affairs and Tourism, Mafikeng.

MARCO, A., DUTOIT, T., DESCHAMPS-COTTIN, M., MAUFFREY, J., VENNETIER, M. \& BERTAUDIERE-MONTES, V. 2008. Gardens in urbanizing rural areas reveal an unexpected floral diversity related to housing density. Comptes Rendus Biologies 331: 452-465.

MATHIEU, R., FREEMAN, C. \& ARYAL, J. 2007. Mapping private gardens in urban areas using object-oriented techniques and very high-resolution satellite imagery. Landscape and Urban Planning 81: 179-192.

MATSON, P.A., PARTON, W.J., POWER, A.G. \& SWIFT, M.J. 1997. Agricultural intensification and ecosystem properties. Science 277: 504-509.

MCKINNEY, M.L. 2008. Effects of urbanization on species richness: a review of plants and animals. Urban Ecosystems 11: 161-176.

MILLENNIUM ECOSYSTEM ASSESSMENT. 2003. Ecosystems and human well-being: a framework for assessment. Island Press, Washington DC

MOLEBATSI, L.Y., SIEBERT, S.J., CILLIERS, S.S., LUBBE, C.S. \& DAVOREN, E. 2010. The Tswana tshimo: a home garden system of useful plants with a particular layout and function. African Journal of Agricultural Research 5: 2952-2963.

MUCINA, L. \& RUTHERFORD, M.C. (eds). 2006. The vegetation of South Africa, Lesotho and Swaziland. Strelitzia 19. South African National Biodiversity Institute, Pretoria.

NIINEMETS, Ü. \& PEÑUELAS, J. 2008. Gardening and urban landscaping: significant players in global change. Trends in Plant Science 13: 60-65.

PICKETT, S.T.A., CADENASSO, M.L., GROVE, J.M., NILON, C.H., POUYAT, R.V., ZIPPERER, W.C. \& COSTANZA, R. 2001. Urban ecological systems: linking terrestrial ecological, physical and socio-economic components of metropolitan areas. Annual Review of Ecology and Systematics 32: 127-157.

PIENAAR, K. 1994. The ultimate southern African gardening book. Southern Book Publishers, Pretoria.

PIENAAR, K. 2000. The South African what flower is that? Struik, Cape Town.

PIMENTEL, D., LACH, L., ZUNIGA, R. \& MORRISON, D. 2000. Environmental and economic costs of nonindigenous species in the United States. BioScience 50: 53-65.

RAIMONDO, D., VON STADEN, L., FODEN, W., VICTOR, J.E., HELME, N.A., TURNER, R.C., KAMUNDI, D.A. \& MANYAMA, P.A. 2009. Red List of South African plants 2009. Strelitzia 25. South African National Biodiversity Institute, Pretoria.
REBELE, F. 1994. Urban ecology and special features of urban ecosystems. Global Ecology and Biogeography Letters 4: 173-187.

RICHARDSON, D.M., ROUGET, M., RALSTON, S.J., COWLING R.M., VAN RENSBURG, B.J. \& THUILLER, W. 2005. Species richness of alien plants in South Africa: environmental correlates and the relationship with indigenous plant species richness. Ecoscience 12: 391-402.

RICHARDSON, D.M. \& VAN WILGEN, B.W. 2004. Invasive alien plants in South Africa: how well do we understand the ecological impacts? South African Journal of Science 100: 45-52.

SAVARD, J.L., CLERGEAU, P. \& MENNECHEZ, G. 2000. Biodiversity concepts and urban ecosystems. Landscape and Urban Planning 48: 131-142.

SIEBERT, S.J., ZOBOLO, A.M. \& DOWE, J.L. 2010. Livistona chinensis: a first record of a naturalized palm in South Africa. Bothalia 40: 55-57.

SMITH, G.F. \& VAN WYK, B-E. 2008. Guide to garden succulents. Briza Publications, Pretoria

SMITH, R.M., THOMPSON, K., HODGSON, J.G., WARREN, P.H \& GASTON, K.J. 2006. Urban domestic gardens IX: composition and richness of the vascular plant flora, and implications for native biodiversity. Biological Conservation 129: 312-322.

SNYMAN, H. 2009. Top 20 SA plant families (accessed 4 Dec. 2009). H.Snyman@sanbi.org.za.

SOUTH AFRICA. 1983. Conservation of Agricultural Resources Act of 1983. Government Printer, Pretoria.

SULLIVAN, J.J., TIMMINS, S.M. \& WILLIAMS, P.A. 2005. Movement of exotic plants into coastal native forests from gardens in northern New Zealand. New Zealand Journal of Ecology 29: 1-10.

THOMPSON, K., AUSTIN, K.C., SMITH, R.M., WARREN, P.H., ANGOLD, P.G. \& GASTON, K.J. 2003. Urban domestic gardens I: putting small-scale plant diversity in context. Journal of Vegetation Science 14: 71-78.

UNITED STATES DEPARTMENT OF AGRICULTURE (USDA). 2009. Plants database. http://www.plants.usda.gov/ (accessed 3 Feb. 2010).

VAN JAARSVELD, E. 2001. Shaped by suffering. Veld \& Flora 87: 16-19.

VAN WYK, B.-E. \& GERICKE, N. 2000. People's plants: a guide to useful plants of southern Africa. Briza Publications, Pretoria.

WILLIAMS, J.W., SEABLOOM, E.W., SLAYBACK, D., STOMS, D.M. \& VIERS, J.H. 2005. Anthropogenic impacts upon plant species richness and net primary productivity in California. Ecology Letters 8: 127-137.

WORKWELL. 2004. Potchefstroom socio-economic survey. WorkWell research unit for people, policy and performance, Potchefstroom.

WU, J., JENERETTE, G.D. \& DAVID, J. 2003. Linking land-use change with ecosystem processes: a hierarchical patch dynamic model. In S. Guhathakurta, Integrated land use and environmental models: 99-119. Springer, Berlin. 